\title{
'Man-in-the-Barrel' Syndrome with Bilateral 6th Cranial Nerve Palsy
}

\author{
Ivan Rocha Ferreira Da Silva \\ Cleveland Clinic Foundation, Cleveland, Ohio, USA
}

A 39-year-old previously healthy man was admitted comatose (Hunt-Hess scale of 5) after suffering a subarachnoid hemorrhage. A digital subtraction angiography revealed a $13.6 \times 15 \times 19 \mathrm{~mm}$, right vertebrobasilar junction aneurysm. The aneurysm was coiled during the procedure (fig. 1). After regaining consciousness, his neurological exam revealed severe proximal weakness of the upper extremities associated with bilateral 6th cranial nerve palsy. An MRI of the brain showed aneurysmal compression of the mid-pons. There are reports of 'man-in-the barrel' syndrome secondary to osmotic demyelination [1] or ischemic strokes [2] of the pons, but not secondary to pontine compression (fig. 2).

\section{References}

1 Deleu D, Salim K, Mesraoua B, El Siddig A, Al Hail H, Hanssens Y: 'Man-in-the-barrel' syndrome as delayed manifestation of extrapontine and central pontine myelinolysis: beneficial effect of intravenous immunoglobulin. J Neurol Sci 2005;237:103-106.

2 Paulin M, de Seze J, Wyremblewski P, Zéphir H, Leys D, Vermersch P: Man-in-the-barrel syndrome caused by a pontine lesion. Neurology 2005;64:1703.
Fig. 1. Digital subtraction angiography (lateral view) depicts the giant vertebrobasilar junction aneurysm after coiling. Fig. 2. MRI of the brain shows aneurysmal compression of the mid-pons and residual filling of the neck of the aneurysm in an SPGR sequence T1 weighted with contrast. The DWI and T2-weighted sequences did not reveal parenchymal changes.
1

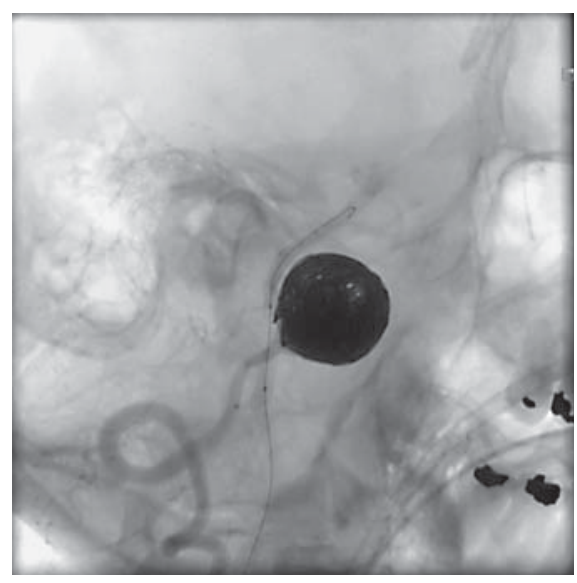

2

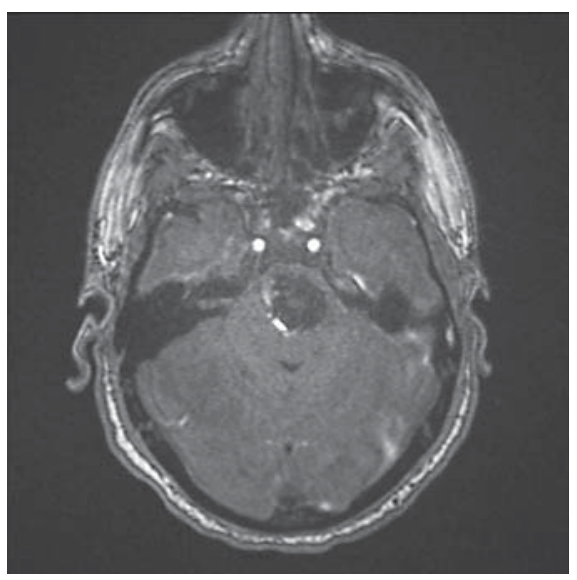

\section{KARGER}

Fax +4161306 1234 E-Mail karger@karger.ch www.karger.com
(C) 2012 S. Karger AG, Basel 0014-3022/12/0686-0367\$38.00/0

Accessible online at:

www.karger.com/ene
Ivan Rocha Ferreira Da Silva Cleveland Clinic Foundation 1132 Churchill Rd

Cleveland, OH 44124 (USA)

E-Mailivanuerj@gmail.com 